\title{
Chemical and mineralogical analyses on stones from Sagunto Castle (Spain)
}

\author{
Mirco Ramacciotti $^{\mathrm{a}, \mathrm{b}}$, Sonia Rubio ${ }^{\mathrm{b}}$, Gianni Gallello ${ }^{\mathrm{b}, \mathrm{c}, *}$, Marco Lezzerini $^{\mathrm{d}, \mathrm{e}}$, Simona Raneri ${ }^{\mathrm{d}}$, \\ Emilia Hernandez ${ }^{\mathrm{f}}$, Matias Calvo ${ }^{\mathrm{f}}$, Stefano Columbu ${ }^{\mathrm{g}}$, Angel Morales ${ }^{\mathrm{b}}$, Agustin Pastor ${ }^{\mathrm{b}}$, \\ Miguel de la Guardiab
}

a Department of Prehistory, Archaeology and Ancient History, Faculty of Geography and History University of Valencia, Av. Blasco Ibánez, 28, 46010, Valencia, Spain
b Department of Analytical Chemistry, University of Valencia, C/ Dr. Moliner 50, 46100 Burjassot, Valencia, Spain
${ }^{\mathrm{c}}$ Department of Archaeology, University of York, King's Manor, YO17EP York, UK
${ }^{\mathrm{d}}$ Department of Earth Sciences, University of Pisa, Via S. Maria 53, 56126 Pisa, Italy
${ }^{\mathrm{e}}$ Applied and Laser Spectroscopy Lab., ICCOM-CNR, Via G. Moruzzi 1, 56124 Pisa, Italy
${ }^{\mathrm{f}}$ Sagunto Archaeological Museum, C/ del Castillo 23, 46500 Sagunto, Valencia, Spain
${ }^{\mathrm{g}}$ Department of Chemical and Geological Sciences, University of Cagliari, Via Trentino 51, 09127 Cagliari, Italy

A R T I C L E IN F O

\section{Keywords:}

Building stone

Fortress

Remains

Chemistry

Mineralogy

Roman period

Middle ages

\begin{abstract}
A B S T R A C T
For the first time, an archaeometric study was carried out on the carbonate rock ashlars of the Sagunto Castle. The studied site is one of the most important and best preserved Spanish archaeological and architectural monuments, characterized by different construction phases from the Roman period to Modern Ages. Forty samples collected from thirteen different structures of Sagunto Castle and two quarries, located in the Sagunto's hill were used for comparative purposes. The samples were analyzed by X-ray diffraction, X-ray fluorescence and inductively coupled plasma mass spectrometry to determine their mineralogical and elemental composition. The obtained data show similar chemical and mineralogical features between the rocks outcropping in the city quarries and some of those employed to build the structures, suggesting that rocks could have been used to build the structures from different periods along the centuries.
\end{abstract}

\section{Introduction}

Chemical and mineralogical analyses of ancient stones have been used to identify raw material provenance and to better understand the constructive phases of both, archaeological sites (Ferrini et al., 2012; Columbu et al., 2014) and architectural monuments (Sammarco et al., 2015; Lezzerini et al., 2017), as well as to understand the exploitation and circulation of raw materials in the past (Dreesen and Dusar, 2004; Storemyr et al., 2007; Antonelli et al., 2014; Gallello et al., 2016). The analysis of the stones used for building ancient monuments could be also useful for conservation purposes, like getting specimens for laboratory tests, identifying replacement stone sources, and better understanding decay processes (Cardell et al., 2003; Brilli et al., 2010; Török and Přikryl, 2010; De Kock et al., 2015; Hopkinson et al., 2015; Aalil et al., 2016; Berthonneau et al., 2016; Lezzerini et al., 2016).

The present research aims to obtain the first chemical and mineralogical data of the stones used in the buildings of the Sagunto Castle, and to estimate their relationship with the stone material identified in the ancient quarries. Taking into account the difficult access to the amount of samples to be collected, allowed by the authorities, a chemical and mineralogical approach was developed on a set of forty building stone samples collected from thirteen different structures of the Castle (Fig. 1) and from two local quarries. Sagunto was inhabited by Iberian people before the $\mathrm{V}$ century BCE, but the expansion of the city and the construction of the most important structures started following the Roman conquest. The Sagunto Castle was characterized by several occupation phases since the Republican Roman period (Aranegui et al., 1987) to the Napoleonic Wars. During the past century, the site was also interested by restoration works and was designated as heritage of cultural interest by the public authorities (Ripollés Alegre and Llorens Forcada, 2004; Monserrat, 2007). Nowadays, this monument is preparing its candidature to be nominated UNESCO world heritage. The structures of the Sagunto Castle were built widely employing stones. The main used lithotypes are from the sedimentary sequences outcropping in the surrounding area of the site, and the Sagunto Castle itself is located on a hill where dolostone, marlstone and dolomitic limestone outcrop (Goy et al., 1972). Furthermore, the archaeologists identified two ancient quarries on the northern side of the hill. In this study, X-ray diffraction (XRD) was used to determine the main mineralogical phases of the samples, while X-ray fluorescence

\footnotetext{
* Corresponding author at: Department of Analytical Chemistry, University of Valencia, C/ Dr. Moliner 50, 46100 Burjassot, Valencia, Spain.

E-mail address: gianni.gallello@york.ac.uk (G. Gallello).
} 


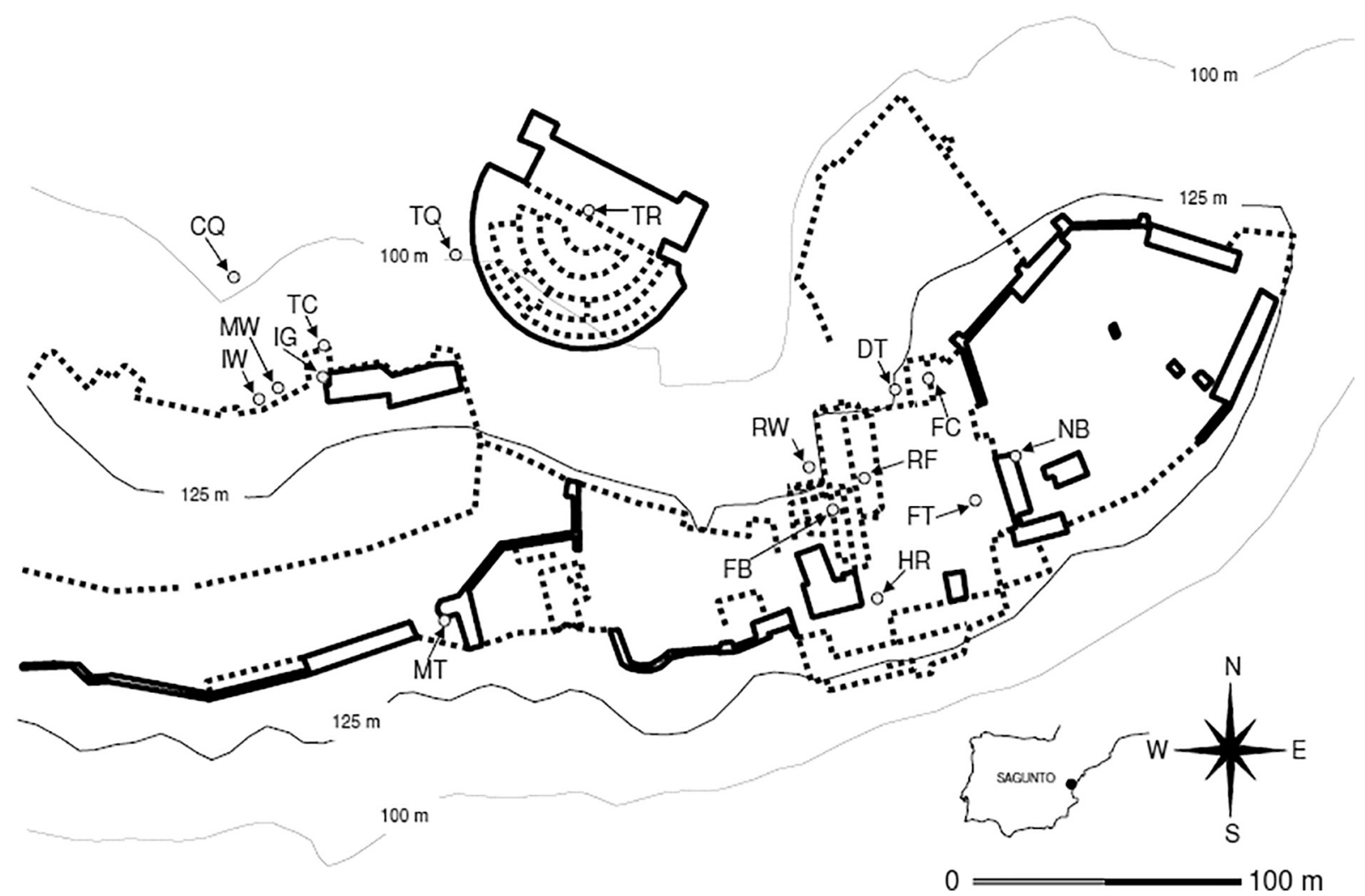

Fig. 1. Map of Sagunto Castle with sampling points (modified from Gallello et al., 2017).

(XRF) and inductively coupled plasma mass spectrometry (ICP-MS) were employed to determine major and minor chemical elements and trace chemical elements, respectively. The obtained data were processed by multivariate statistics.

The importance behind this research is related to the high cultural significance of the Sagunto Castle archaeological site and the unique possibility to produce significant data, which was quite difficult due to the high protective policy that restricts the access to building stone and outcrop sampling.

\section{Materials and methods}

\subsection{Sampling}

Forty stone samples were collected from different structures of the Sagunto Castle. They are representative of the different chronological phases identified during the archaeological studies (Table 1). Due to conservation issues, we were allowed by the authorities to collect just around $1 \mathrm{~g}$ of each sample in order to perform the analysis, limiting the range of analytical methods to be performed. A small surface portion of each ashlar was scraped to remove the external surface, in order to avoid weathered material, and small chips of rock were then collected by using a chisel.

Twenty-two samples were collected from buildings whose foundation was dated to the Roman Republican period (Roman Republican wall, RW; Diana Temple, DT; Republican Forum, RF; Central Estudiantes Tower, TC). However, concerning TC, the archaeological evidence and mortars analysis (Gallello et al., 2017) suggest important reworks in the subsequent phases.

The Roman Imperial phase led to the building of important monumental structure such as the Theatre (TR), from which two samples were collected. Moreover, five samples were collected from the Imperial Forum (Curia, FC; Basilica, FB; Tabernae, FT), an area affected by reworks during the Islamic phase.
As indicative of the Islamic period, begun in the VIII century and endured with reversal of fate until the reconquest of the XIII century, four samples were collected from different buildings (Islamic Gate, IG; Islamic Wall, IW; Moneda Tower, MT). Three samples were also collected from Modern Age buildings (Hermitage, HR; Modern Wall, MW; Napoleonic Barracks, NB).

In order to evaluate the possible relationship between construction building stones and local outcropping sedimentary rocks, four representative samples of the two ancient quarries on the hill of the Sagunto Castle located at Calvario (CQ - Calvario Quarry) and at the Theatre (TQ - Theatre Quarry) areas, were taken. These quarries are formed by dolostone and dolomitic limestone of Triassic "Muschelkalk" outcrop (Goy et al., 1972).

\subsection{Methods}

We have designed an analytical method approach in order to provide reproducible and comparable results compatible with the small amount of available sample. Qualitative mineralogical analyses were carried out on powders through X-ray diffraction (XRD) by using an automatic diffractometer Philips PW 1830/1710 under the following experimental conditions: Bragg-Brentano geometry, Ni-filtered $\mathrm{CuK}_{\alpha}$ radiation obtained at $40 \mathrm{kV}$ and $20 \mathrm{~mA}, 5-60^{\circ} 2 \theta$ investigated range in step of $0.02^{\circ}$ with a counting time per step of $2 \mathrm{~s}$. To identify the mineralogical phases in the X-ray spectra, a search/match approach (DIFFRACPlus EVA) was used by comparing experimental peaks with PDF2 reference patterns.

Major and minor chemical elements were determined by X-ray fluorescence (XRF) on fused glass disks utilizing an ARL $9400 \mathrm{XP}+$ sequential X-ray spectrometer under the instrumental conditions reported by Lezzerini et al. (2013). Within the range of the measured concentrations, the analytical uncertainties determined on international standards vary from $20 \%\left(\mathrm{Na}_{2} \mathrm{O}\right)$ to $1 \%$ relative $(\mathrm{CaO})$, with a mean value of $5 \%$ relative for the major elements (Lezzerini et al., 
Table 1

List and identification of collected samples.

\begin{tabular}{|c|c|c|c|c|c|}
\hline Sample & Building & Period & Sample & Building/quarry & Period \\
\hline RW1 & Republican wall & Roman Republican & RF2 & Republican forum & Roman Republican \\
\hline RW2 & Republican wall & & RF3 & Republican forum & \\
\hline RW3 & Republican wall & & FC1 & Imperial forum Curia & Roman imperial \\
\hline RW4 & Republican wall & & FC2 & Imperial forum Curia & \\
\hline RW5 & Republican wall & & FB1 & Imperial forum basilica & \\
\hline RW6 & Republican wall & & FT1 & Imperial forum tabernae & \\
\hline RW7 & Republican wall & & FT2 & Imperial forum tabernae & \\
\hline RW8 & Republican wall & & TR2 & Theatre & \\
\hline TC1 & Torre central estudiantes & & TR3 & Theatre & \\
\hline TC2 & Torre central estudiantes & & IG1 & Islamic gate & Islamic period \\
\hline TC3 & Torre central estudiantes & & IG2 & Islamic gate & \\
\hline TC4 & Torre central estudiantes & & IW1 & Islamic wall & \\
\hline TC5 & Torre central estudiantes & & MT1 & Moneda tower & \\
\hline TC6 & Torre central estudiantes & & HR1 & Hermitage & Modern ages \\
\hline TC7 & Torre central estudiantes & & MW1 & Modern wall & \\
\hline TC8 & Torre central estudiantes & & NB1 & Napoleonic barrack & \\
\hline TC9 & Torre central estudiantes & & CQ1 & Calvario quarry & - \\
\hline DT1 & Republican Diana temple & & CQ2 & Calvario quarry & - \\
\hline DT2 & Republican Diana temple & & TQ1 & Theatre quarry & - \\
\hline RF1 & Republican forum & & TQ2 & Theatre quarry & - \\
\hline
\end{tabular}

2013; Lezzerini et al., 2014). The total amount of volatile components was determined as loss on ignition (LOI) in $105-950^{\circ} \mathrm{C}$ temperature range.

Trace elements (Ba, Bi, Cd, Cr, Co, Cu, Pb, Li, Mn, Mo, Ni, Sr, Tl, V, $\mathrm{Zn}$ ), REE (La, Ce, Pr, Nd, Sm, Eu, Gd, Tb, Dy, Ho, Er, Tm, Yb, Lu), Sc and $\mathrm{Y}$ were determined by ICP-MS. The dissolution of homogenized samples was carried out by adding $1.35 \mathrm{ml}$ of hydrochloric acid and $0.45 \mathrm{ml}$ of nitric acid (using high purity $37 \% \mathrm{HCl}$ and $69 \% \mathrm{HNO}_{3}$ ) to $0.15 \mathrm{~g}$ of sample in glass tubes, while placing them in a water bath at $100{ }^{\circ} \mathrm{C}$ for $40 \mathrm{~min}$. The obtained solutions were cautiously transferred into plastic tubes of $50 \mathrm{ml}$ and diluted up to $15 \mathrm{ml}$ with purified water. The calibration standards were prepared from a stock solution for ICP analysis in $\mathrm{HNO}_{3} 5 \%(\mathrm{w} / \mathrm{v})$, containing the mentioned elements at a concentration of $100 \mu \mathrm{g} / \mathrm{ml}$. Solutions were analyzed with a Perkin Elmer Elan DRCII ICP-MS (Concord, Ontario, Canada). Digested Samples were filtered employing filter paper (Whatman ${ }^{\mathrm{TM}} \mathrm{N} .1,70 \mathrm{~mm}$ ) to eliminate the insoluble residue and to avoid the obstruction of the nebulization system. Concentrations between 1 and $600 \mu \mathrm{g} / \mathrm{l}$ were used for calibration purpose of most of the elements $(\mathrm{Ba}, \mathrm{Bi}, \mathrm{Cd}, \mathrm{Cr}, \mathrm{Co}, \mathrm{Cu}, \mathrm{Pb}, \mathrm{Li}, \mathrm{Mn}$, Mo, Ni, Sr, Tl, V, Zn, La, Ce, Pr, Nd), and concentrations between 1 and $100 \mu \mathrm{g} / \mathrm{l}$ for Sm, Eu, Gd, Tb, Dy, Ho, Er, Tm, Yb, Lu. All standards were purchased from Sharlab S.L. (Barcelona). Soil JDo-1 and limestone NCS DC73375 certified materials were used to control the quality of measurements. Rhodium was used as internal standard.

Selected major and trace elements data obtained on studied stone samples were processed through multivariate statistics. Specifically, Principal Component Analysis (PCA) was carried out employing 40 samples and 21 variables $\left(\mathrm{Na}_{2} \mathrm{O}, \mathrm{MgO}, \mathrm{CaO}, \mathrm{MnO}, \mathrm{Fe}_{2} \mathrm{O}_{3} \mathrm{~T}\right.$, REE, $\mathrm{Y}$ and $\mathrm{Sc}$ ). This statistic method was used to explore large geochemical datasets reducing the number of variables and providing a deep insight into the structure of their variance. Data were pre-processed through mean centering and autoscaling. Venetian blind cross validation was carried out as the way to test the prediction capability of the built model. The PLS Toolbox 8.2 for Eigenvector Research Inc. (Wenatchee, WA, USA) running in the software MatlabR2016b from Mathworks Inc. (Natick, MA, USA) was used for statistical treatments.

\section{Results and discussion}

\subsection{Mineralogical composition}

The collected XRD spectra (Table 2) revealed that calcite and dolomite are the main mineralogical phases in the studied samples. So, looking at calcite and dolomite relative amounts, the presence of almost three different lithotypes could be estimated:

Group 1: limestones characterized by the presence of calcite and traces of dolomite (19 samples: RW1-6, RW8, TC1, DT1, RF1, FC1-2, FB1, FT1, TR2-3, IG1-2, MW1);

Group 2: calcitic dolostones characterized by high contents of dolomite and traces or small amounts of calcite (10 samples: TC4, TC6, TC8-9, RF2, IW1, HR1, NB1, TQ1-2);

Group 3: stones characterized by high amount of calcite and dolomite, even with different relative proportion (11 samples: RW7, TC2-3, TC5, TC7, DT2, RF3, FT2, MT1, CQ1-2).

Additionally, minor contents of quartz were detected in each sample and a small amount of feldspars was found in samples of the second and third group. Furthermore, traces of phyllosilicates in sample RF2 and small amount of gypsum in the samples from the Islamic Gate (IG1-2) were found. In limestone gypsum is a typical secondary mineral in limestone that can be produced by the reaction of calcite and sulfuric acid due to environmental chemical alterations as air pollution (Charola et al., 2007). However it is difficult to understand if the presence of this mineral is due to the conservation state of the masonries, since it was detected only in the Islamic Gate samples.

\subsection{Major and minor elements}

Chemical XRF data reported in Table 2 indicates that $\mathrm{MgO}$ and $\mathrm{CaO}$ are the most representative components of the analyzed samples showing a strong negative correlation (Fig. 2a). These results confirm those obtained by mineralogical analyses, in fact according to Frolova classification of calcite-dolomite series (Frolova, 1959), $\mathrm{CaO} / \mathrm{MgO}$ ratio can be used to discriminate between calcite- and dolomite-rich carbonate rocks. Based on the aforementioned classification criterion, the $\mathrm{CaO} / \mathrm{MgO}$ ratio was calculated in order to verify discriminations inferred by mineralogical composition, and better define the geological nature of rock samples in which both calcite and dolomite were identified.

Samples of Group 1 exhibit a $\mathrm{CaO} / \mathrm{MgO}$ ratio > 50.1, confirming the previous classification as limestones; samples of Group 2, identified as calcitic dolostones by XRD data, can be precisely defined as slightly calcitic dolostones, being characterized by a $\mathrm{CaO} / \mathrm{MgO}$ ratios ranging from 1.8 to 2.0. For all the other samples, the calculated $\mathrm{CaO} / \mathrm{MgO}$ ratios allow us to discriminate calcitic dolostones $(\mathrm{CaO} / \mathrm{MgO}$ ratios from 2.3 to 3.3: TC5, DT2, RF3, FT2 and CQ1), dolomitic limestones $(\mathrm{CaO} / \mathrm{MgO}$ ratios of $4.2, \mathrm{RW7}$, and $8.3, \mathrm{CQ} 2)$, and slightly dolomitic 
Table 2

Main mineralogical phases of Sagunto Castle samples and estimated amounts of oxides determined by XRF, XRD, and their volatile components (LOI).

\begin{tabular}{|c|c|c|c|c|c|c|c|c|c|c|c|c|c|c|c|c|c|c|}
\hline Sample & $\mathrm{Cal}$ & Dol & Qtz & Fsp & Other & L.O.I. & $\mathrm{Na}_{2} \mathrm{O}$ & $\mathrm{MgO}$ & $\mathrm{Al}_{2} \mathrm{O}_{3}$ & $\mathrm{SiO}_{2}$ & $\mathrm{P}_{2} \mathrm{O}_{5}$ & $\mathrm{~K}_{2} \mathrm{O}$ & $\mathrm{CaO}$ & $\mathrm{TiO}_{2}$ & $\mathrm{MnO}$ & $\mathrm{Fe}_{2} \mathrm{O}_{3 \mathrm{~T}}$ & $\mathrm{CaO} / \mathrm{MgO}$ & Classification \\
\hline RW1 & $\mathrm{XXX}$ & $\operatorname{tr}$ & $\mathrm{X}$ & - & - & 42.8 & 0.02 & 0.95 & 0.43 & 1.69 & 0.08 & 0.28 & 53.2 & 0.03 & 0.01 & 0.47 & 56.0 & Ls. \\
\hline RW2 & $\mathrm{XXX}$ & - & $\mathrm{X}$ & - & - & 38.4 & 0.03 & 0.57 & 0.71 & 11.6 & 0.09 & 0.27 & 48.1 & 0.02 & 0.01 & 0.31 & 84.4 & Ls. \\
\hline RW3 & $\mathrm{XXX}$ & - & $\mathrm{X}$ & - & - & 41.5 & 0.03 & 0.86 & 1.26 & 3.25 & 0.13 & 0.69 & 51.7 & 0.06 & 0.01 & 0.56 & 60.1 & Ls. \\
\hline RW4 & $\mathrm{XXX}$ & - & $\mathrm{X}$ & - & - & 42.1 & 0.05 & 0.54 & 0.89 & 2.37 & 0.08 & 0.49 & 52.9 & 0.05 & 0.01 & 0.46 & 98.0 & Ls. \\
\hline RW5 & $\mathrm{XXX}$ & - & $\mathrm{X}$ & - & - & 43.1 & 0.02 & 0.57 & 0.31 & 1.14 & 0.07 & 0.20 & 54.2 & 0.02 & 0.01 & 0.37 & 95.0 & Ls. \\
\hline RW6 & $\mathrm{XXX}$ & - & $\mathrm{X}$ & - & - & 42.8 & 0.02 & 0.55 & 0.47 & 1.45 & 0.14 & 0.26 & 53.7 & 0.02 & 0.02 & 0.52 & 97.7 & Ls. \\
\hline RW7 & $\mathrm{XX}$ & $\mathrm{XXX}$ & $\mathrm{X}$ & $\mathrm{X}$ & - & 43.4 & 0.01 & 5.73 & 0.49 & 1.71 & 0.09 & 0.27 & 47.4 & 0.04 & 0.05 & 0.82 & 8.3 & Dolomitic ls. \\
\hline RW8 & $\mathrm{XXX}$ & - & $\mathrm{X}$ & - & - & 43.1 & 0.02 & 0.63 & 0.36 & 1.03 & 0.08 & 0.24 & 54.1 & 0.02 & 0.01 & 0.45 & 85.8 & Ls. \\
\hline TC1 & $\mathrm{XXX}$ & $\operatorname{tr}$ & $\mathrm{X}$ & - & - & 42.7 & 0.02 & 1.01 & 0.55 & 1.79 & 0.15 & 0.38 & 53.0 & 0.04 & 0.01 & 0.44 & 52.4 & Ls. \\
\hline TC2 & $\mathrm{XXX}$ & $\mathrm{X}$ & $\mathrm{X}$ & - & - & 42.1 & 0.02 & 2.55 & 1.12 & 2.54 & 0.11 & 0.72 & 50.1 & 0.07 & 0.02 & 0.73 & 19.6 & Slightly dolomitic ls. \\
\hline TC3 & $\mathrm{XXX}$ & $\mathrm{x}$ & $\mathrm{X}$ & - & - & 42.1 & 0.03 & 2.15 & 0.98 & 2.44 & 0.15 & 0.64 & 50.7 & 0.06 & 0.01 & 0.70 & 23.6 & Slightly dolomitic ls. \\
\hline TC4 & $\operatorname{tr}$ & $\mathrm{XXX}$ & $\mathrm{X}$ & $\mathrm{X}$ & - & 43.6 & $<$ LOD & 16.7 & 1.25 & 2.81 & 0.14 & 0.61 & 32.3 & 0.07 & 0.13 & 2.34 & 1.9 & Slightly calcitic dls. \\
\hline TC5 & $\mathrm{xx}$ & $\mathrm{XXX}$ & $\mathrm{X}$ & $\mathrm{X}$ & - & 42.4 & 0.02 & 12.9 & 1.87 & 3.52 & 0.12 & 0.92 & 36.0 & 0.12 & 0.10 & 2.01 & 2.8 & Calcitic dls. \\
\hline TC6 & $\operatorname{tr}$ & $\mathrm{XXX}$ & $\mathrm{X}$ & $\mathrm{X}$ & - & 43.6 & 0.01 & 16.7 & 1.20 & 2.52 & 0.17 & 0.58 & 32.3 & 0.09 & 0.10 & 2.74 & 1.9 & Slightly calcitic dls. \\
\hline TC7 & $\mathrm{XXX}$ & $\mathrm{XX}$ & $\mathrm{X}$ & - & - & 41.8 & 0.04 & 4.40 & 1.16 & 2.67 & 0.08 & 0.56 & 47.1 & 0.08 & 0.08 & 2.00 & 10.7 & Slightly dolomitic ls. \\
\hline TC8 & $\operatorname{tr}$ & $\mathrm{XXX}$ & $\mathrm{X}$ & $\mathrm{X}$ & - & 44.9 & $<$ LOD & 16.9 & 0.47 & 1.88 & 0.10 & 0.23 & 33.8 & 0.03 & 0.04 & 1.66 & 2.0 & Slightly calcitic dls. \\
\hline TC9 & $\operatorname{tr}$ & $\mathrm{XXX}$ & $\mathrm{X}$ & $\mathrm{X}$ & - & 44.7 & 0.02 & 17.1 & 0.60 & 1.82 & 0.11 & 0.24 & 33.3 & 0.03 & 0.14 & 1.96 & 1.9 & Slightly calcitic dls. \\
\hline DT1 & $\mathrm{XXX}$ & - & $\mathrm{X}$ & - & - & 42.2 & 0.03 & 0.88 & 0.83 & 2.38 & 0.08 & 0.52 & 52.5 & 0.04 & 0.01 & 0.51 & 59.7 & Ls. \\
\hline DT2 & $\mathrm{XX}$ & $\mathrm{XXX}$ & $\mathrm{X}$ & $\mathrm{X}$ & - & 45.1 & $<$ LOD & 15.4 & 0.39 & 1.32 & 0.10 & 0.17 & 36.0 & 0.02 & 0.06 & 1.38 & 2.3 & Calcitic dls. \\
\hline $\mathrm{RF} 1$ & $\mathrm{XXX}$ & $\operatorname{tr}$ & $\mathrm{X}$ & - & - & 42.8 & 0.04 & 0.78 & 0.44 & 1.37 & 0.07 & 0.26 & 53.5 & 0.02 & 0.01 & 0.64 & 68.6 & Ls. \\
\hline RF2 & $\operatorname{tr}$ & $\mathrm{xXX}$ & $\mathrm{X}$ & $\mathrm{X}$ & Phyll (tr) & 44.0 & 0.02 & 17.0 & 0.90 & 2.40 & 0.19 & 0.41 & 32.4 & 0.06 & 0.13 & 2.43 & 1.9 & Slightly calcitic dls. \\
\hline RF3 & $\mathrm{XX}$ & $\mathrm{xxx}$ & $\mathrm{X}$ & $\mathrm{X}$ & - & 44.4 & 0.02 & 12.5 & 0.62 & 1.23 & 0.22 & 0.25 & 39.3 & 0.04 & 0.07 & 1.34 & 3.1 & Calcitic dls. \\
\hline FC1 & $\mathrm{xxx}$ & - & $\mathrm{X}$ & - & - & 43.0 & 0.04 & 0.61 & 0.42 & 1.15 & 0.06 & 0.24 & 53.9 & 0.02 & 0.01 & 0.52 & 88.4 & Ls. \\
\hline FC2 & $\mathrm{XXX}$ & $\operatorname{tr}$ & $\mathrm{X}$ & - & - & 42.6 & 0.04 & 0.76 & 0.55 & 2.09 & 0.07 & 0.32 & 53.2 & 0.03 & 0.01 & 0.36 & 70.0 & Ls. \\
\hline FB1 & $\mathrm{XXX}$ & - & $\mathrm{X}$ & - & - & 41.9 & 0.03 & 0.79 & 1.08 & 2.62 & 0.08 & 0.63 & 52.3 & 0.05 & 0.01 & 0.60 & 66.1 & Ls. \\
\hline FT1 & $\mathrm{XXX}$ & $\operatorname{tr}$ & $\mathrm{X}$ & - & - & 42.5 & 0.03 & 0.91 & 0.61 & 1.80 & 0.08 & 0.35 & 52.8 & 0.03 & 0.02 & 0.86 & 58.1 & Ls. \\
\hline FT2 & $\mathrm{XX}$ & $\mathrm{XXX}$ & $\mathrm{X}$ & $\mathrm{X}$ & - & 44.23 & 0.02 & 14.99 & 0.54 & 2.2 & 0.07 & 0.25 & 35.51 & 0.03 & 0.13 & 2.03 & 2.4 & Calcitic dls. \\
\hline TR2 & $\mathrm{XXX}$ & - & $\mathrm{X}$ & - & - & 43.4 & 0.02 & 0.82 & 0.25 & 0.77 & 0.10 & 0.13 & 54.1 & 0.02 & 0.01 & 0.37 & 66.0 & Ls. \\
\hline TR3 & $\mathrm{XXX}$ & - & $\mathrm{X}$ & - & - & 41.9 & 0.04 & 0.77 & 1.02 & 2.62 & 0.10 & 0.66 & 52.3 & 0.06 & 0.02 & 0.56 & 67.9 & Ls. \\
\hline IG1 & $\mathrm{XXX}$ & - & $\mathrm{X}$ & - & $\mathrm{Gp}(\mathrm{X})$ & 43.1 & 0.21 & 0.59 & 0.31 & 1.01 & 0.11 & 0.34 & 54.1 & 0.02 & 0.01 & 0.25 & 91.6 & Ls. \\
\hline IG2 & $\mathrm{XXX}$ & - & $\mathrm{X}$ & - & $\mathrm{Gp}(\mathrm{X})$ & 43.2 & 0.17 & 0.49 & 0.27 & 0.76 & 0.32 & 0.26 & 54.3 & 0.01 & 0.01 & 0.20 & 110.9 & Ls. \\
\hline IW1 & $\operatorname{tr}$ & $\mathrm{XXX}$ & $\mathrm{X}$ & $\mathrm{X}$ & - & 45.1 & 0.02 & 17.4 & 0.59 & 1.32 & 0.13 & 0.26 & 33.3 & 0.03 & 0.11 & 1.72 & 1.9 & Slightly calcitic dls. \\
\hline MT1 & $\mathrm{XXX}$ & $\mathrm{X}$ & $\mathrm{X}$ & - & - & 42.5 & 0.06 & 1.84 & 0.72 & 2.17 & 0.08 & 0.49 & 51.6 & 0.03 & 0.01 & 0.49 & 28.0 & Slightly dolomitic ls. \\
\hline HR1 & $\operatorname{tr}$ & $\mathrm{XXX}$ & $\mathrm{X}$ & $\mathrm{X}$ & - & 43.5 & 0.04 & 17.5 & 1.25 & 3.31 & 0.08 & 0.58 & 31.1 & 0.08 & 0.15 & 2.37 & 1.8 & Slightly calcitic dls. \\
\hline MW1 & $\mathrm{xxx}$ & - & $\mathrm{X}$ & - & - & 41.8 & 0.08 & 0.51 & 0.84 & 2.57 & 0.24 & 0.33 & 52.6 & 0.05 & 0.02 & 1.03 & 103.0 & Ls. \\
\hline NB1 & $\operatorname{tr}$ & $\mathrm{xxx}$ & $\mathrm{X}$ & $\mathrm{X}$ & - & 43.8 & $<$ LOD & 16.6 & 1.30 & 2.59 & 0.10 & 0.67 & 32.8 & 0.08 & 0.14 & 1.94 & 2.0 & Slightly calcitic dls. \\
\hline CQ1 & $\mathrm{xx}$ & $\mathrm{XXX}$ & $\mathrm{X}$ & $\mathrm{X}$ & - & 44.1 & $<$ LOD & 12.0 & 0.65 & 1.58 & 0.08 & 0.31 & 39.5 & 0.04 & 0.04 & 1.69 & 3.3 & Calcitic dls. \\
\hline CQ2 & $\mathrm{xx}$ & $\mathrm{XxX}$ & $\mathrm{X}$ & $\mathrm{X}$ & - & 43.8 & $<$ LOD & 9.92 & 0.57 & 1.55 & 0.08 & 0.27 & 42.1 & 0.03 & 0.03 & 1.63 & 4.2 & Dolomitic ls. \\
\hline TQ1 & $\operatorname{tr}$ & $\mathrm{XXX}$ & $\mathrm{X}$ & $\mathrm{X}$ & - & 40.9 & 0.02 & 16.2 & 2.84 & 6.46 & 0.14 & 1.16 & 29.6 & 0.16 & 0.13 & 2.34 & 1.8 & Slightly calcitic dls. \\
\hline TQ2 & $\operatorname{tr}$ & $\mathrm{xxx}$ & $\mathrm{X}$ & $\mathrm{X}$ & - & 43.1 & 0.01 & 17.2 & 1.86 & 3.84 & 0.08 & 0.80 & 31.1 & 0.13 & 0.09 & 1.83 & 1.8 & Slightly calcitic dls. \\
\hline
\end{tabular}

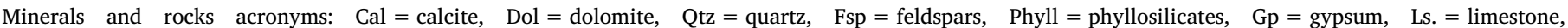

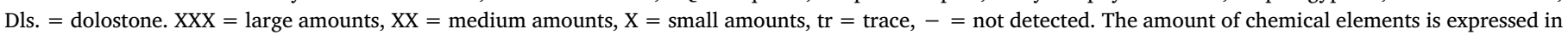
weight percentage. L.O.I. $=$ loss on ignition $\left(950^{\circ} \mathrm{C}\right) ; \mathrm{Fe}_{2} \mathrm{O}_{3} \mathrm{~T}=$ total iron expressed as $\mathrm{Fe}_{2} \mathrm{O}_{3} ;<\mathrm{LOD}=$ under the limit of detection.

limestones ( $\mathrm{CaO} / \mathrm{MgO}$ ratios from 10.7 to 28.0: TC2, TC3, TC7, and MT1).

Concerning the significance of other major elements, usually iron and manganese oxides are directly correlated to the presence of dolomite (Morrow, 1982); effectively, while in samples characterized by medium and high amounts of this mineral $\mathrm{Fe}_{2} \mathrm{O}_{3} \mathrm{~T}$ ranges from 0.82 to $2.74 \mathrm{wt} \%$ (mean: $1.90 \pm 0.46 \mathrm{wt} \%$ ) and $\mathrm{MnO}$ from 0.03 to $0.15 \mathrm{wt} \%$ (mean: $0.10 \pm 0.04 \%$ ), in limestones $\mathrm{Fe}_{2} \mathrm{O}_{3} \mathrm{~T}$ ranges from 0.20 to $1.03 \mathrm{wt} \%$ (mean: $0.52 \pm 0.19 \mathrm{wt} \%$ ) and $\mathrm{MnO}$ from 0.01 to $0.02 \mathrm{wt} \%$ (mean: $0.012 \pm 0.004 \mathrm{wt} \%$ ). The compositional differences among the possible sedimentary rocks types identified on the basis of $\mathrm{CaO} / \mathrm{MgO}$ ratio are also evidenced by trends shown in the binary diagrams reported in Fig. $2 \mathrm{~b}$ and $\mathrm{c}$.

Concerning elements useful to inspect the conservation state of building materials and, the possible degradation processes of structures, it is noteworthy that IG1 and IG2 show contents of $\mathrm{Na}_{2} \mathrm{O}$ one order of magnitude higher than in the other samples: namely 0.21 and $0.17 \mathrm{wt}$ $\%$, respectively. Such a high amount of sodium could be related to the presence of soluble salts responsible for severe decay in buildings (Charola et al., 2007). On the contrary, the low amount of sodium in dolomitic limestones and dolostones, as compared to limestones, could be explained by the diagenesis process of these rocks (Abdel-Rahman and Nader, 2002). On the other hand, it must be noticed that TQ1 is characterized by a high content of $\mathrm{SiO}_{2}(6.46 \%)$, although the highest value was detected in sample RW2 (11.55\%), while the stones collected from TQ quarry show high amounts of $\mathrm{TiO}_{2}$ (TQ1: $0.16 \%$ and TQ2: $0.13 \%)$.

\subsection{Trace elements analysis}

Table 3 shows the results of trace element analysis performed through ICP-MS, expressed in $\mu \mathrm{g} / \mathrm{g}$. Regarding the total amount of REE ( $\Sigma$ REE), all the samples contained from 1.2 to $28 \mu \mathrm{g} / \mathrm{g}$, except limestone samples RW2, MW1 and TR2, which have anomalous high concentrations of lanthanides: 84, 100 and $114 \mu \mathrm{g} / \mathrm{g}$, respectively. These samples have also high amounts of yttrium (RW2: $9 \mu \mathrm{g} / \mathrm{g}$, MW: $29 \mu \mathrm{g} / \mathrm{g}$ and TR2: $22 \mu \mathrm{g} / \mathrm{g}$ ), while the others contain this element from 0.2 to $3 \mu \mathrm{g} / \mathrm{g}$. Scandium vary from 0.6 to $16 \mu \mathrm{g} / \mathrm{g}$. In general, the limestone samples $(29 \pm 23 \mu \mathrm{g} / \mathrm{g}$ ) show averagely higher $\Sigma \mathrm{REE}$ values than the ashlars of the other carbonate rocks $(12 \pm 6 \mu \mathrm{g} / \mathrm{g})$ and the quarry samples ( $6 \pm 2 \mu \mathrm{g} / \mathrm{g}$ ), also excluding the above-quoted anomalous values. The limestone samples are also characterized by high amounts of strontium ranging from 78 to $3003 \mu \mathrm{g} / \mathrm{g}(796 \pm 781 \mu \mathrm{g} / \mathrm{g})$ while the other samples range between 46 and $1211 \mu \mathrm{g} / \mathrm{g}$ for ashlars $(184 \pm 306 \mu \mathrm{g} / \mathrm{g})$, and between 37 and $112 \mu \mathrm{g} / \mathrm{g}$ for quarry rock $(66 \pm 35 \mu \mathrm{g} / \mathrm{g})$. On the other hand, $\mathrm{Cr}$ and $\mathrm{Li}$ are higher in dolomite limestone and dolostone samples, both from buildings ( $39 \pm 50 \mu \mathrm{g} / \mathrm{g}$ and $1.4 \pm 0.9 \mu \mathrm{g} / \mathrm{g}$ ) and quarries $(50 \pm 28 \mu \mathrm{g} / \mathrm{g}$ and $1.8 \pm 0.8 \mu \mathrm{g} / \mathrm{g})$, than in limestone ones 

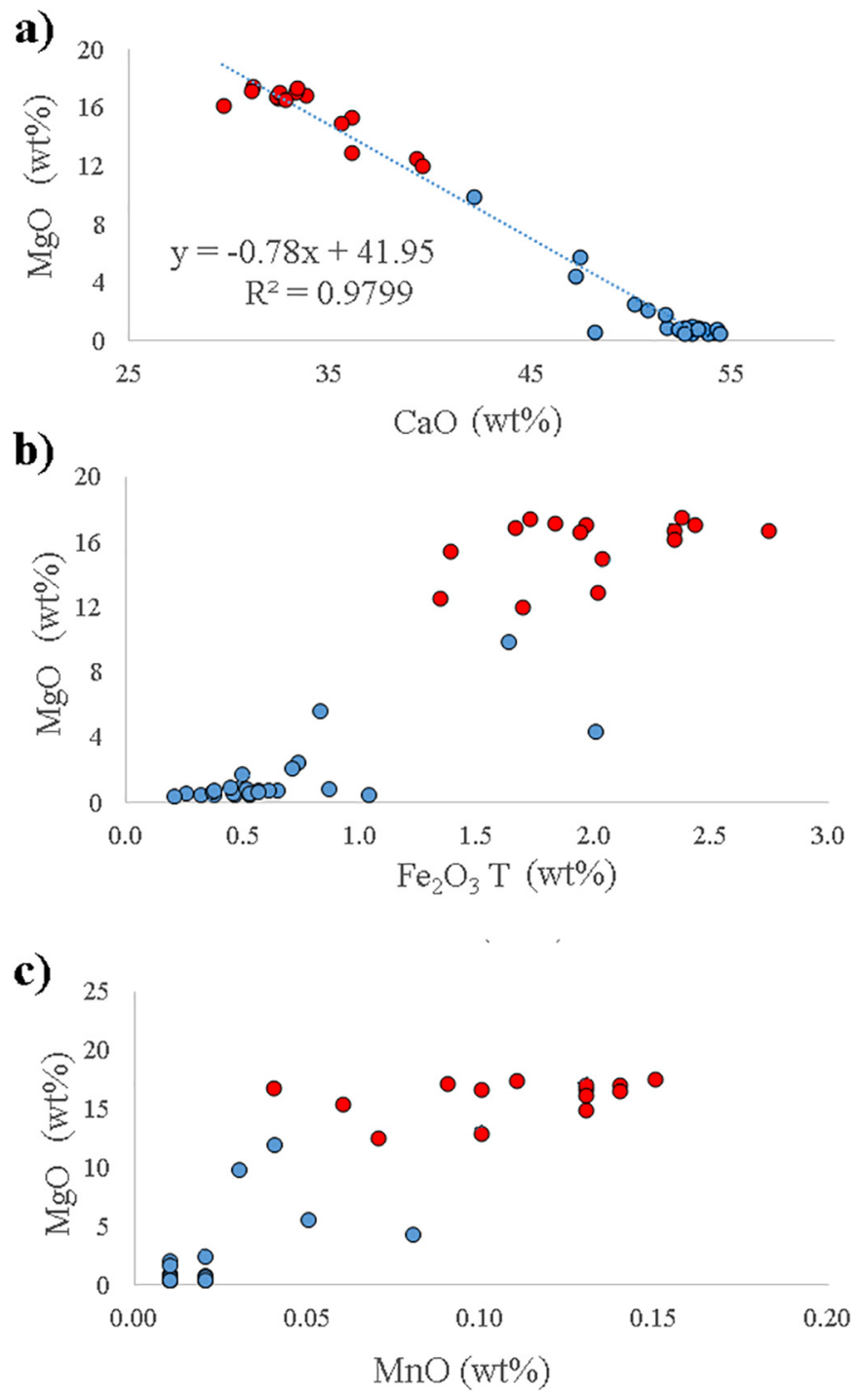

Fig. 2. Binary diagrams (a) $\mathrm{CaO}$ vs. $\mathrm{MgO}$; (b) Fe2O3T vs. $\mathrm{MgO}$; (c) $\mathrm{MnO}$ vs. MgO. Legenda: red circles = calcitic dolostone; blue circles $=$ limestone and dolomitic limestone.

$(16 \pm 22 \mu \mathrm{g} / \mathrm{g}$ and $0.9 \pm 0.7 \mu \mathrm{g} / \mathrm{g})$. Furthermore, dolomite limestonedolostone ashlars and quarry samples have higher levels of $\mathrm{Zn}$ $(31 \pm 28 \mu \mathrm{g} / \mathrm{g}$ and $51 \pm 46 \mu \mathrm{g} / \mathrm{g}$ respectively) than limestone ones (21 $\pm 22 \mu \mathrm{g} / \mathrm{g}$ ), and the first ones have higher concentrations of $\mathrm{Pb}$ $(22 \pm 17 \mu \mathrm{g} / \mathrm{g})$ than limestone and quarry samples $(13 \pm 12 \mu \mathrm{g} / \mathrm{g}$ and $14 \pm 13 \mu \mathrm{g} / \mathrm{g}$ respectively). Other trace elements were found in comparable concentrations in the three types of samples.

\subsection{Statistical data processing}

Multivariate statistics was carried out to evaluate the similarities and differences among the analyzed samples by applying PCA. In order to reduce the number of variables which could describe appropriately the samples, $\mathrm{Na}_{2} \mathrm{O}, \mathrm{MgO}, \mathrm{CaO}, \mathrm{MnO}, \mathrm{Fe}_{2} \mathrm{O}_{3} \mathrm{~T}$, REE, $\mathrm{Y}$ and Sc of the whole set of samples were used (Fig. 3) due to the important role of these elements on the sedimentary rock composition (Schieber, 1988; Nothdurft et al., 2004; Zhang et al., 2017).

Just two principal components (PC1 and PC2) explain 58.04\% and $17.98 \%$ of the variance, respectively, and loadings of PC1 and PC2 are correlated with their contribution to the overall model (Fig. 3, bottom). REE data especially contribute on PC1 direction, while PC2 is particularly influenced by major elements (Fig. 3, bottom). Specifically, PC1 accounts La, Ce, Pr, Nd, Sm, Eu, Gd, Dy, Ho, Er, Tm, Yb, Lu and Y variability and higher values of REE mean higher values of PC1. Otherwise, the influence of $\mathrm{Na}_{2} \mathrm{O}, \mathrm{MgO}, \mathrm{CaO}, \mathrm{MnO}$ and $\mathrm{Fe}_{2} \mathrm{O}_{3} \mathrm{~T}$ in discriminating different lithotypes is evidenced by PC2 scores; as can be seen, $\mathrm{Na}_{2} \mathrm{O}$ and $\mathrm{CaO}$, and $\mathrm{MgO}, \mathrm{MnO}$ and $\mathrm{Fe}_{2} \mathrm{O}_{3} \mathrm{~T}$ inversely contribute to the computation of PC2, meaning that higher values of the first elements, typical of limestone, lead to negative values on y-axis and higher values of the latter ones, typical of magnesian carbonate rocks, lead to positive ones.

The inspection of scores plot shown in the top of Fig. 3 allows to discriminate two main sample populations: in PC2 positive direction, samples exhibiting the presence of dolomite, classified from slightly dolomitic limestones (TC7 and RW7) to calcitic dolostones, are grouped together with the samples taken from both studied local quarries (labeled as TQ and CQ). Conversely, limestone ashlars and most of the slightly dolomitic limestones are grouped on the bottom of the plot. It is noteworthy that dolomitic stones seem to exhibit a more homogenous composition than limestones, which span in a larger area credibly resembling the variability in REE values.

Samples MW1, RW2 and TR2 seem to be outliers as compared with the rest of rocks. It is interesting to note that these limestone ashlars belong to diachronic structures, being correlated only by the high REE levels in the analyzed set. This feature could be related to peculiar sedimentary diagenetic conditions, post-depositional processes or even to restoration works.

\subsection{Considerations on provenance of raw materials and construction phases}

The chemical and mineralogical results of stones sampled from Sagunto Castle, are showing the five different facies of dolostone and limestone lithologies (calcitic dolostones, slightly calcitic dolostones, dolomitic limestones, slightly dolomitic limestones and limestones) all of them outcropping in the sedimentary sequence of the Sagunto area as indicated by Goy et al. (1972). This discrimination, suggested by chemical and mineralogical data, has been confirmed by the relative amounts of $\mathrm{CaO}$ and $\mathrm{MgO}$ (Fig. 2) and by the variability in minor and trace elements (Fig. 3).

Concerning provenance issues, the first test seems to indicate a compositional semblance between dolomite-rich ashlars (slightly calcitic dolostone, calcitic dolostone, dolomitic limestone, and slightly dolomitic limestone) and stone samples from local quarries. Furthermore, the representative samples taken from the ancient quarries show a slightly different mineralogical composition, covering the whole range of carbonate rocks: the stones from Theatre Quarry may be classified as slightly calcitic dolostones, while the Calvario Quarry materials may span from calcitic dolostone to dolomitic limestone. In fact, the fortress of Sagunto Castle is built on the rock outcrop of Triassic "Muschelkalk" lithologies, which show different intermediate facies from dolostone to dolomitic limestone. The lithotypes sampled from the Sagunto Castle structures maybe indicate that the stones employed could be from those local quarries. Regarding limestones, until now no local ancient quarries have been identified in the closeness of Sagunto, although the area is interested by the occurrence of this lithotype just few kilometers south-west and north-west of the archaeological site. In this latter area, some Triassic "Buntsandstein" limestones of Lias (Pliensbachiense, Sinemuriense, Hettangiense) also appear, together with dolomites, bioclastic-limestones and carniolas. Within a radius of $5 \mathrm{~km}$ from the Castle various limestone facies of Dogger and Lower Malm (Oxfordiense) and marly limestones with nodules were also identified (Goy et al., 1972).

If we try to find a relation between the different lithotypes and the construction phases of the Castle, it can be observed that limestones have been employed in all Imperial buildings (i.e.: Curia, Basilica and Theatre, with the exception of FT2 sample), in the Islamic Gate and in the Modern Wall. Limestone ashlars occur with a non-systematic 
Table 3

Trace elements in Sagunto Castle samples determined through ICP-MS analysis.

\begin{tabular}{|c|c|c|c|c|c|c|c|c|c|c|c|c|c|c|c|c|c|}
\hline Sample & $\Sigma$ REEs & ${ }^{209} \mathrm{Bi}$ & ${ }^{207} \mathrm{~Pb}$ & ${ }^{205} \mathrm{Tl}$ & ${ }^{138} \mathrm{Ba}$ & ${ }^{111} \mathrm{Cd}$ & ${ }^{95} \mathrm{Mo}$ & ${ }^{89} \mathrm{Y}$ & ${ }^{88} \mathrm{Sr}$ & ${ }^{64} \mathrm{Zn}$ & ${ }^{63} \mathrm{Cu}$ & ${ }^{60} \mathrm{Ni}$ & ${ }^{59} \mathrm{Co}$ & ${ }^{52} \mathrm{Cr}$ & ${ }^{51} \mathrm{~V}$ & ${ }^{45} \mathrm{Sc}$ & ${ }^{7} \mathrm{Li}$ \\
\hline RW1 & 14 & $<$ LOD & 4 & 0.010 & 5 & 0.07 & 3 & 2 & 576 & 16 & 1.7 & 140 & 5 & 21 & $<$ LOD & 1.3 & 0.6 \\
\hline RW2 & 84 & 0.07 & 26 & 0.04 & 6 & 0.09 & 2 & 9 & 2109 & 2 & 1.4 & 12 & 0.7 & 11 & $<$ LOD & 4 & 1.9 \\
\hline RW3 & 1.2 & $<$ LOD & 0.5 & $<$ LOD & 16 & 0.006 & 0.5 & 0.2 & 143 & 26 & 1.2 & 420 & 33 & 2 & 11 & 4 & 0.6 \\
\hline RW4 & 9 & 0.001 & 5 & $<$ LOD & 42 & 0.02 & 2 & 1.1 & 1907 & 5 & 0.9 & 62 & 2 & 7 & 25 & 1.3 & 0.8 \\
\hline RW5 & 3 & $<$ LOD & 0.3 & $<$ LOD & 5 & 0.005 & 0.3 & 0.6 & 364 & 28 & 0.2 & 466 & 20 & 3 & $<$ LOD & 2 & 0.4 \\
\hline RW6 & 16 & 0.02 & 3 & 0.06 & 12 & 0.03 & 6 & 1.9 & 432 & 4 & 1.1 & 12 & 0.9 & 7 & 7 & 0.7 & 0.7 \\
\hline RW7 & 9 & $<$ LOD & 3 & $<$ LOD & 0.4 & 0.2 & 3 & 1.4 & 49 & 128 & 5 & 1584 & 93 & 25 & 5 & 6.8 & 2 \\
\hline RW8 & 14 & $<$ LOD & 6 & 0.02 & 5 & 0.04 & 3 & 1.9 & 617 & 8 & 1.8 & 64 & 2 & 7 & $<$ LOD & 1.3 & 0.9 \\
\hline TC1 & 29 & 0.05 & 46 & 0.06 & 2 & 0.14 & 2 & 2 & 718 & 45 & 3 & 18 & 1.1 & 8 & 4 & 1.7 & 3 \\
\hline TC2 & 28 & 0.05 & 44 & 0.05 & 6 & 0.14 & 2 & 2 & 694 & 43 & 3 & 18 & 1.04 & 7 & 3 & 1.7 & 3 \\
\hline TC3 & 1.9 & $<$ LOD & 0.4 & $<$ LOD & 5 & 0.005 & 0.08 & 0.3 & 196 & 43 & 1.2 & 572 & 37 & 1.5 & $<$ LOD & 1.9 & 0.96 \\
\hline TC4 & 15 & 0.003 & 37 & 0.015 & 6 & 0.03 & 4 & 2 & 61 & 27 & 5 & 27 & 3 & 190 & $<$ LOD & 1.6 & 1.1 \\
\hline TC5 & 11 & 0.012 & 22 & 0.03 & 22 & 0.10 & 3 & 2 & 62 & 18 & 5 & 9 & 1.2 & 7 & $<$ LOD & 1.2 & 0.8 \\
\hline TC6 & 12 & 0.06 & 27 & 0.05 & 21 & 0.02 & 6 & 2 & 83 & 18 & 4 & 17 & 5 & 52 & $<$ LOD & 1.3 & 1.7 \\
\hline TC7 & 13 & 0.02 & 30 & 0.03 & 0.8 & 0.12 & 12 & 2 & 160 & 36 & 4 & 51 & 1.7 & 18 & 20 & 1.8 & 1.9 \\
\hline TC8 & 4 & 0.007 & 4.5 & 0.012 & 9 & 0.03 & 9 & 0.9 & 110 & 39 & 4 & 86 & 4 & 39 & 78 & 1.5 & 3.8 \\
\hline TC9 & 8 & $<$ LOD & 13 & $<$ LOD & 27 & 0.05 & 3 & 1.5 & 46 & 30 & 1.9 & 191 & 7 & 10 & $<$ LOD & 2 & 0.6 \\
\hline DT1 & 21 & 0.08 & 23 & 0.2 & 25 & 0.03 & 0.2 & 2 & 1255 & $<$ LOD & 1.1 & 15 & 0.9 & 7 & $<$ LOD & 1.1 & 1.5 \\
\hline DT2 & 12 & 0.02 & 16 & 0.04 & 45 & 0.05 & 0.9 & 1.3 & 62 & 9 & 1.9 & 24 & 1.6 & 24 & 17 & 0.7 & 1.1 \\
\hline $\mathrm{RF} 1$ & 12 & 0.02 & 26 & 0.08 & 16 & 0.24 & 0.8 & 2 & 78 & 19 & 3 & 19 & 1.5 & 88 & 22 & 0.6 & 0.3 \\
\hline RF2 & 12 & 0.03 & 8 & 0.03 & 13 & 0.03 & 0.5 & 2 & 53 & 9 & 2 & 21 & 1.6 & 16 & 12 & 1.1 & 0.7 \\
\hline RF3 & 7 & 0.04 & 65 & 0.06 & 18 & 0.02 & 0.6 & 1.1 & 57 & 14 & 2 & 21 & 1.1 & 9 & 20 & 1.0 & 0.5 \\
\hline FC1 & 18 & 0.06 & 6 & 0.2 & 7 & 0.006 & 0.2 & 1.7 & 528 & $<$ LOD & 0.8 & 22 & 1.1 & 4 & $<$ LOD & 0.8 & 0.5 \\
\hline FC2 & 20 & 0.03 & 10 & 0.04 & 17 & $<$ LOD & 0.2 & 1.3 & 3003 & 1.0 & 2 & 28 & 1.5 & 11 & 5 & 1.2 & 1.6 \\
\hline FB1 & 25 & 0.15 & 14 & 0.4 & 8 & 0.06 & 0.3 & 2 & 577 & 2 & 2 & 20 & 1.2 & 10 & $<$ LOD & 0.8 & 0.7 \\
\hline FT1 & 23 & 0.13 & 16 & 0.3 & 10 & 0.005 & 0.5 & 2 & 583 & 8 & 1.4 & 23 & 1.4 & 10 & $<$ LOD & 0.7 & 0.6 \\
\hline FT2 & 20 & 0.08 & 36 & 0.3 & 7 & 0.05 & 0.99 & 3 & 85.7 & 15 & 4 & 22 & 3.1 & 31 & 59 & 2 & 1.4 \\
\hline TR2 & 115 & 0.09 & 5 & 0.07 & 26 & 0.09 & 2 & 22 & 287 & 88 & 30 & 46 & 19 & 63 & 82 & 8 & 0.03 \\
\hline TR3 & 14 & 0.007 & 0.9 & 0.007 & 14 & 0.02 & 0.13 & 3 & 246 & 4 & $<\mathrm{LOD}$ & 35 & 2 & $<\mathrm{LOD}$ & 7 & 1.1 & 0.003 \\
\hline IG1 & 19 & 0.010 & 20 & 0.02 & 9 & 0.05 & 1.1 & 2 & 1249 & 31 & 2 & 27 & 1.3 & 6 & $<$ LOD & 1.1 & 1.6 \\
\hline IG2 & 12 & 0.02 & 28 & 0.03 & 23 & 0.12 & 11 & 1.5 & 150 & 33 & 4 & 48 & 1.6 & 16 & 19 & 1.7 & 1.8 \\
\hline IW1 & 9 & 0.014 & 10 & 0.04 & 14 & 0.05 & 1.1 & 2 & 67 & 33 & 5 & 13 & 1.9 & 107 & 49 & 0.9 & 2 \\
\hline MT1 & 18 & 0.002 & 26 & 0.05 & 16 & 0.05 & 0.06 & 2 & 1211 & 27 & 2 & 25 & 1.3 & 5 & $<$ LOD & 0.8 & 0.5 \\
\hline HR1 & 10 & 0.04 & 15 & 0.09 & 9 & $<$ LOD & 0.5 & 1.5 & 43.6 & 3 & 3 & 14 & 2 & 19 & 7 & 1.3 & 0.96 \\
\hline MW1 & 101 & 0.019 & 17 & 0.12 & 26 & 1.16 & 0.2 & 29 & 305 & 27 & 4 & 28 & 2 & 10 & $<$ LOD & 1.8 & 0.55 \\
\hline NB1 & 18 & 0.03 & 20 & 0.04 & 13 & 0.07 & 0.5 & 2 & 89 & 35 & 4 & 27 & 2 & 103 & 14 & 1.7 & 0.94 \\
\hline CQ1 & 3 & 0.008 & 8 & $<$ LOD & 47 & 0.10 & 14 & 0.8 & 76 & 44 & 5 & 389 & 15 & 29 & 135 & 6 & 2.47 \\
\hline CQ2 & 8 & 0.02 & 34 & 0.10 & 9 & 0.11 & 6 & 1.3 & 112 & 18.1 & 5 & 39 & 3 & 88 & 5 & 0.9 & 1.3 \\
\hline TQ1 & 6 & 0.011 & 12 & $<\mathrm{LOD}$ & 139 & 0.03 & 5 & 2 & 41 & 24.2 & 3 & 110 & 5 & 27 & 68 & 4 & 0.95 \\
\hline TQ2 & 5 & 0.003 & 1.8 & $<\mathrm{LOD}$ & 5 & 0.08 & 5.3 & 1.1 & 37 & 119 & 6 & 1228 & 77 & 55 & 182 & 16 & 2.63 \\
\hline
\end{tabular}

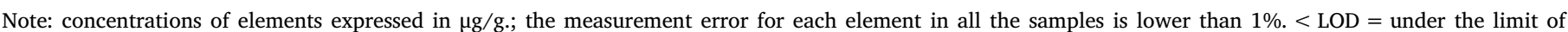
detection.

distribution in some Republican structures, such as the Republican Forum (RF1), Diana Temple (DT1) and the Central Estudiantes Tower (TC1). It is worth noticing that the Republican wall seems to be entirely constructed by using this lithotype (samples labeled as RW), with the sole exception of RW7, which shows an affinity with the Calvario Quarry materials (specifically, CQ2 sample). In the other studied structures, materials were possibly taken from Calvario and Theatre quarries, even if not thoroughly employed.

This first overview could suggest interesting historical and archaeological observations, especially by crossing the present results with the ones of the mortar analysis showed in Gallello et al. (2017) and Ramacciotti et al. (2018). First of all, limestone ashlars were used in most of the samples from buildings dating back to the Roman Ages, suggesting a prevalent use of raw materials from quarries outside the city, being exploited through Republican and Imperial periods. The occurrence of dolomitic-type stones similar to the rocks outcropping in the city quarries in almost all the investigated structures suggests the possible uninterrupted use of construction materials coming from the quarries of Calvario and Theatre. Though the exploitation of the two quarries inside the city during the Roman period would be possible, these cases of urban quarries could find a comparable example in the small quarry of PERI2 in Tarragona (Gutiérrez Garcia-M, 2011). Moreover, the use of these stones in the Republican Forum (FR), in the Republican Wall (RW) and in Diana Temple (DT), whose masonries were dated back to the Roman Republican period through mortar analysis (Gallello et al., 2017), seems to point out the presence of at least two construction phases during this period or the presence of some architectural intervention on these structures during the following periods. However, it is worth noting that dolomite-rich rocks were used in buildings whose mortars evidenced Islamic (TCE, FT, HR, IW and TM) and Modern (TCE, NP) construction phases (Gallello et al., 2017; Ramacciotti et al., 2018), suggesting a possible heavy exploitation of the city quarries during Medieval and Modern Ages. In conclusion, the occurrence of all the identified stone types in the overall archaeological area supports the considerations, suggested by the previous archaeological and archaeometric studies on Sagunto Castle mortars (Gallello et al., 2017), according to which heavy reworks interested most of the buildings from the Roman period to the Modern Ages.

\section{Conclusions}

This study have demonstrated the capability of chemical and mineral analyses in discriminating carbonate rocks and supporting archaeological studies, providing information on raw materials provenance and reconstruction of architectural phases, also when just a small amount of sample can be collected.

The results suggest that the dolomitic rock facies (mainly calcitic dolostones and dolomitic limestones) used to erect the Sagunto Castle maybe come from the local "Theatre" and "Calvario" quarries. Trace elements, REE, Y and Sr showed to be good discriminators of these 

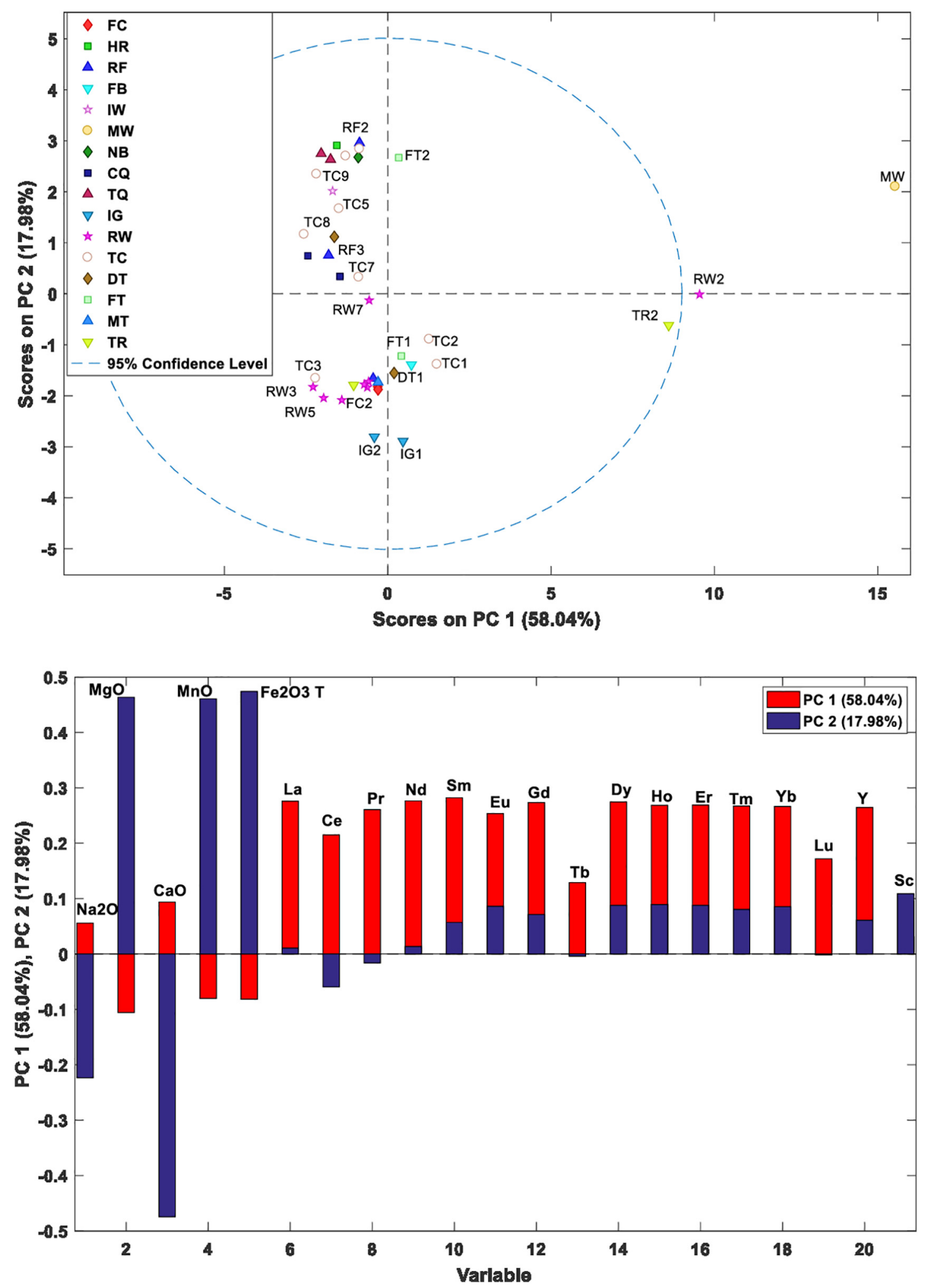

Fig. 3. Principal component analysis through selected oxides and REEs data. Scores biplot (top) and loadings plot (bottom).

rocks from the others. The lower variability in these elements enforces the above-quoted provenance hypothesis of dolomitic limestones and dolostones.

Regarding the limestone facies, although no extraction front or ancient quarry have been recognized near to the archaeological site, it is likely that these stones come from the outcrops located next to the castle (within about $2 \mathrm{~km}$ ), where lithologies similar to those used in the castle were found. No conclusions can be inferred by the higher variability of both lanthanides, yttrium and $\mathrm{Sr}$ in limestone ashlars due to the impossibility of identifying the ancient quarries and determining the variability of the possible raw materials. However, REE and Y point out the presence of three limestone samples characterized by abnormally high values (RW2, MW1 and TR2).

The results suggest the presence of different construction phases in 
RW, RF and FT during the Republican period. Limestone from the unidentified quarries outside the city could have been preferentially used during the Roman Ages, while calcitic dolostone and dolomitic limestone possibly extracted from the urban quarries seems to be especially exploited during the Islamic period and Modern Ages, as suggested by their preferential employment in buildings like TCE, FT, HR, IW, TM and NP.

This study provides a unique opportunity to chemically screen this important site, which is being considerate as a candidate to be declared a UNESCO world heritage. The unsystematic occurrence of the different identified lithotypes in the studied buildings enforces the idea of a complex architectural history of the Sagunto Castle, characterized by reworks and whose complete understanding is probably only at its starting point.

\section{Acknowledgments}

Authors acknowledge the financial support of Generalitat Valenciana, Spain (PROMETEO project II/2014/077); Ministerio de Economía y Competitividad, Spain- Feder (Project CTQ 2014-52841-P and Project CTQ 2012-38635).

The authors would like to thanks all the students of Chemistry and Archaeology, which have contributed to the realization of this study.

Gianni Gallello acknowledges the financial support of the European Commission (Project H2020-MSCA-IF-2015-704709-MATRIX).

Finally the authors are grateful to the reviewers for their useful suggestions and comments.

\section{References}

Aalil, I., Beck, K., Brunetaud, X., Cherkaoui, K., Chaaba, A., Al-Mukhtar, M., 2016. Deterioration analysis of building calcarenite stone in the House of Venus in the archaeological site of Volubilis (Morocco). Const. Build. Mater. 125, 1127-1141.

Abdel-Rahman, A.F.M., Nader, F.H., 2002. Characterization of the Lebanese JurassicCretaceous carbonate stratigraphic sequence: a geochemical approach. Geol. J. 37, 69-91.

Antonelli, F., Columbu, S., Lezzerini, M., Miriello, D., 2014. Petrographic characterization and provenance determination of the white marbles used in the Roman sculptures of Forum Sempronii (Fossombrone, Marche, Italy). Appl. Phys. A Mater. Sci. Process. 115, 1033-1040.

Aranegui, C., Hernández, E., López, M., 1987. El foro de Saguntum: la planta arquitectónica. In: Los foros romanos de las provincias occidentales, Ministerio de Cultural, Madrid, pp. 73-97.

Berthonneau, J., Bromblet, P., Cherblanc, F., Ferrage, E., Vallet, J.M., Grauby, O., 2016. The spalling decay of building bioclastic limestones of Provence (South East of France): from clay minerals swelling to hydric dilation. J. Cult. Heritage 17, 53-60.

Brilli, M., Antonelli, F., Giustini, F., Lazzarini, L., Pensabene, P., 2010. Black limestones used in antiquity: the petrographic, isotopic and EPR database for provenance determination. J. Archaeol. Sci. 37, 994-1005.

Cardell, C., Delalieux, F., Roumpopoulos, K., Moropoulou, A., Auger, F., Van Grieken, R., 2003. Salt-induced decay in calcareous stone monuments and buildings in a marine environment in SW France. Const. Build. Mater. 17, 165-179.

Charola, A.E., Pühringer, J., Steiger, M., 2007. Gypsum: a review of its role in the deterioration of building materials. Environ. Geol. 52, 339-352.

Columbu, S., Antonelli, F., Lezzerini, M., Miriello, D., Adembri, B., Blanco, A., 2014. Provenance of marbles used in the Heliocaminus baths of Hadrian's Villa (Tivoli, Italy). J. Archaeol. Sci. 49, 332-342.

De Kock, T., De Boever, W., Dewanckele, J., Boone, M.A., Jacobs, P., Cnudde, V., 2015. Characterization, performance and replacement stone compatibility of building stone in the 12th century tower of Dudzele (Belgium). Eng. Geol. 184, 43-51.
Dreesen, R., Dusar, M., 2004. Historical building stones in the province of Limburg (NE Belgium): role of petrography in provenance and durability assessment. Mater. Charact. 53, 273-287.

Ferrini, V., De Vito, C., Mignardi, S., Fucinese, D.V., 2012. Archaeological carved slabs of the Langobard art in churches of Peligna Valley and Spoleto (Italy): provenance of the stones. J. Archaeol. Sci. 39, 3505-3515.

Frolova, E.K., 1959. On classification of carbonate rocks of limestone-dolomite-magnesite series. Novosti Neft. Tekhniki (Geology) 3, 34-35.

Gallello, G., Orozco, T., Pastor, A., de la Guardia, M., Bernabeu, G., 2016. Regional provenance of dolerite prehistoric objects through mineral analysis. Microchem. J. 24, 167-174.

Gallello, G., Ramacciotti, M., Lezzerini, M., Hernandez, E., Calvo, M., Morales, A., Pastor A., de la Guardia, M., 2017. Indirect chronology method employing rare earth elements to identify Sagunto Castle mortar construction periods. Microchem. J. 132, $251-261$.

Goy, J.L., Gutiérrez, M., Pedraza, J., Vegas, R., Zazo, C., 1972. Mapa geológico de la Hoja $n^{\circ} 668$ (Sagunto), Mapa Geológico de España E. 1:50.000, Segunda Serie (MAGNA), $1^{\text {a }}$ ed. Instituto Geológico y Minero de España, Madrid.

Gutiérrez Garcia-M, A., 2011. The exploitation of local stone in Roman times: the case of north-eastern Spain. World Archaeol. 43 (2), 318-341.

Hopkinson, L., Rutt, K., Kristova, P., Blows, J., Firth, C., 2015. Sourcing limestone masonry for restoration of historic buildings, a spectroscopic pilot study. J. Cult. Heritage 16, 822-830.

Lezzerini, M., Tamponi, M., Bertoli, M., 2013. Reproducibility, precision and trueness of $\mathrm{X}$-ray fluorescence data for mineralogical and/or petrographic purposes. Atti della Società Toscana di Scienze Naturali, Memorie, Serie A 120, 67-73.

Lezzerini, M., Tamponi, M., Bertoli, M., 2014. Calibration of XRF data on silicate rocks using chemicals as in-house standards. Atti della Società Toscana di Scienze Naturali, Memorie, Serie A 121, 65-70.

Lezzerini, M., Antonelli, F., Columbu, S., Gadducci, R., Marradi, A., Miriello, D., Parodi, L., Secchiari, L., Lazzeri, A., 2016. The documentation and conservation of the cultural heritage: 3D laser scanning and Gis techniques for thematic mapping of the stonework of the Façade of St. Nicholas Church (Pisa, Italy). Int. J. Archit. Heritage 10, 9-19.

Lezzerini, M., Antonelli, F., Gallello, G., Ramacciotti, M., Parodi, L., Alberti, A., Pagnotta, S., Legnaioli, S., Palleschi, V., 2017. Provenance of marbles used for building the internal spiral staircase of the bell tower of St. Nicholas Church (Pisa, Italy). Appl. Phys. A Mater. Sci. Process. 123, 385.

Monserrat, J.M.M., 2007. Dos siglos de destrucción de Patrimonio Histórico de Sagunto (1807-2007). Arse 41, 231-262.

Morrow, D.W., 1982. Diagenesis 1. Dolomite - part 1: the chemistry of dolomitization and dolomite precipitation. Geosci. Can. 9, 5-13.

Nothdurft, L.K., Webb, G.E., Kamber, B.S., 2004. Rare earth element geochemistry of Late Devonian reefal carbonates, Canning Basin, Western Australia: confirmation of a seawater REE proxy in ancient limestones. Geochim. Cosmochim. Acta 68, 263-283.

Ramacciotti, M., Rubio, S., Gallello, G., Lezzerini, M., Columbu, S., Hernandez, E., Morales-Rubio, A., Pastor, A., de la Guardia, M. 2018. Chronological classification of ancient mortars employing spectroscopy and spectrometry techniques: Sagunt (Valencia, Spain) case. J. Spectrosc. (doi:https://doi.org/10.1155/2018/9736547).

Ripollés Alegre, P.P., Llorens Forcada, M.M., 2004. OPVLENTISSIMA SAGVNTVM. Fundación Bancaja, Sagunto.

Sammarco, M., Margiotta, S., Foresi, L.M., Ceraudo, G., 2015. Characterization and provenance of building materials from the Roman Pier at San Cataldo (Lecce, Southern Apulia, Italy): a lithostratigraphical and micropaleonthological approach. Mediterr. Archaeol. Archaeom. 15, 101-112.

Schieber, J., 1988. Redistribution of rare-earth elements during diagenesis of carbonate rocks from the mid-Proterozoic Newland formation, Montana, U.S.A. Chemical Geol 69, 111-126.

Storemyr, P., Degryse, P., King, J.F., 2007. A black Tournai "marble" tombslab from Belgium imported to Trondheim (Norway) in the 12th century: provenance determination based on geological, stylistic and historical evidence. Mater. Charact. 58, 1104-1118.

Török, Á., Přikryl, R., 2010. Current methods and future trends in testing, durability analyses and provenance studies of natural stones used in historical monuments. Eng. Geol. 115, 139-142.

Zhang, K., Li, Q., Yan, L., Zeng, L., Lu, L., Zhang, Y., Hui, J., Jin, X., Tang, X., 2017 Geochemistry of limestones deposited in various plate tectonic settings. Earth-Science Rev 167, 27-46. 